DOI https://doi.org/10.30525/978-9934-26-173-2-10

\title{
ДОСЛІДЖЕННЯ РЕСУРСНОСТІ ЗАМІСНОГО БАТЬКІВСТВА ЯК ПЕРЕУМОВА УСПІШНОГО ФУНКЦІОНУВАННЯ
}

\author{
Синякова В. Б. \\ кандидат педагогічних наук, доцент, \\ докторант \\ Інститут психології ім. Г. С. Костюка НАПН Украӥни \\ м. Київ, Україна
}

Переміщення дитини-сироти в будь-яку форму замісного батьківства, незалежно від форми сімейного устрою (патронат, прийомна сім'я,), породжує безліч проблем. Мінімізація ризиків замісного батьківства можлива на основі розвиненої системи відбору, навчання та супроводу замісних сімей та попереднього вивчення їх ресурсів.

Класичні дослідження замісного батьківства здійснюються через призму спадковості та генетики [5], психодинаміки [10], соціальних ролей [8], когнітивний розвиток [7], та сімейні системи [6]. Але актуальність проблеми успішного функціонування замісного батьківства і ефективності соціалізації дитини в цій системі вимагає детального аналізу ресурсів замісної сім'ї та ії життєдіяльності.

Ресурси сім'ї-це внутрішні та зовнішні фактори, які можуть бути застосованими членами сім'ї або соціальними працівником у процесі реалізації сім'єю складаних завдань, це так звані "сильні сторони" сім'ї: особисті якості іiі членів, культурний рівень, матеріальне забезпечення, соціальне оточення тощо. Сімейні ресурси складаються з індивідуальних психологічних ресурсів кожного члена сім'ї та ресурсів, які притаманні сім'ї як системі. Під індивідуальними психологічними ресурсами ми розуміємо фізіологічні, когнітивні, особистісні, соціально-психологічні якості та властивості суб'єкта, до яких він звертається в моменти стресу та складних життєвих ситуацій $з$ метою їх подолання. До ресурсів ми відносимо: прийняття себе та інших, впевненість у собі, вміння розпізнавати потенційно стресові ситуації та контролювати рівень стресу, а також матеріальну забезпеченість. Зазвичай ресурси усвідомлюються і розцінюються людиною як власність, тому $\epsilon$ безпосередня можливість до їх накопичення/витрачання, розвитку та видозміни. Під сімейними ресурсами ми розуміємо цінні соціальні, економічні, психологічні, емоційні та фізичні якості, які члени сім’і використовують при відповіді на стресор. Поряд з індивідуальними ресурсами замісного батьківства наявність сформованих сімейних 
ресурсів та вміння ними користуватися, сприяють взаємній адаптації сім'ї та прийомної дитини, подолання можливих труднощів та подальшого розвитку сім'ї [1, с. 112; 2, с. 198].

У ресурсних сім'ях сімейні та індивідуальні ресурси пов'язані між собою, посилюючи цим загальну ресурсність сім'ї. Це надвє сім'ям можливість не відчувати свою безпорадність у важких життєвих ситуаціях, долати стреси, виходячи в результаті на більш високий рівень функціонування [6]. Важливо також розуміти особливості поєднання ресурсів залежно від структурних характеристик сім'ї та етапів іiі життєвого циклу, а також особливостей та відмінностей, які існують в індивідуальних та сімейних ресурсах у кандидатів замісного батьківства [3, с. 460].

Ми вважаємо, що ресурсний підхід у вивченні замісного батьківства сім'ї $€$ найбільш перспективним, оскільки він дозволяє акцентувати процес соціально-психологічного супроводу на ресурсності кожного члена та сім'ї в цілому, а не на виявленні «дисфункціональних» та «патологічних» характеристик. Визначення пріоритетності сімейних та індивідуальних ресурсів на етапі створення форми замісного батьківства дозволить формувати необхідні компетентності та загалом життездатність сімейної системи. Відсутність необхідного системного підходу до проблеми діагностики, навчання та супроводу замісного батьківства ставить під сумнів прогноз успішностї соціалізації дитини в сім'ї. Оцінка ресурсів сім'ї та потреб прийомної дитини, попереднє навчання майбутніх батьків, a також подальша їх підтримка професіоналами знижує ризики «вторинного сирітства» та жорстокого поводження 3 дітьми у прийомних сім'ях [8]. Отже фахівці, які здійснюватимуть навчання та супровід форм замісного батьківства мають володіти інформацією щодо сімейних та індивідуальних ресурсів та факторів ризику сімей. Тому логічною $є$ попередня психологічна діагностика батьків кандидатів з позииії ресурсності сім'ї та ї̈ життездатності.

На сьогодні феномен замісного батьківства розглядаються через призму медичної моделі: сім'я після появи в ній дитини- сироти має вже орієнтована на iï маргіналізовану субкультуру, що визначається особливостями соціального та психологічного здоров'я[9]. Реалізація моделі здійснюється через відповідні методи психологічної діагностики (проводиться діагностика ризиків, психологічних та поведінкових характеристик особистості, які можуть бути визначені як протипоказання для виконання функцій замісних батьків). На певному етапі психологічного обстеження такий підхід $є$ необхідним, оскільки дозволяє виявити ту чи іншу дефіцитність подружжя та сім'ї. Разом 3 
тим важливо усвідомлювати, що, залишаючись у парадигмі медичної моделі, проблеми кандидатів у замісні батьки розглядаються односторонньо: оцінюються тільки ризики. Соціальна модель створення форм замісного батьківства передбачає вивчення ресурсів та життєздатність сім’ї, пошук сильних сторін, які можна розвивати та використовувати у складній життєвій ситуації ( виховання підлітка-сироти). В цьому розумінні, поняття життєздатності поєднує дефіцитність та ресурсність замісного батьківства. Діагностика життєдіяльності може біти здійснена за допомогою тестів та напівструктурованого інтерв'ю, що мають на меті вивчення факторів ризику в контексті соціуму, однолітків, культури, здоров'я, особистісних та поведінкових характеристик, та захисних факторів у всіх вищезазначених сферах. Даний підхід дає можливість, виявивши дефіцитність сім’ї або одного 3 подружжя в будь-якій сфері, цілеспрямовано його компенсувати, спираючись на внутрішні ресурси, а також на ресурси соціального оточення, що є найбільш ефективною стратегією. У зв’язку вважаємо за доцільне використовувати дві групи параметрів кандидатів у замісні батьки: перша група - це параметри-протипоказання, до них відносяться психопатології, агресивність, жорстокість, схильність до алкоголізму тощо (можуть стосуватися як окремих членів, так і потенційної сім’ї, що заміщає, в цілому). Друга група параметри-показання, які можна розцінювати як ресурси сім’ї, до цієї групи можна віднести особистісні складові життєздатності, значущі для взаємодії «замісні батьки прийомна дитина».

Програма психологічного обстеження кандидатів у замісні батьки -це комплекс діагностичних методик, що пропонується кандидатам відповідно до діагностичного алгоритму.

I етапом $\epsilon$ діагностика 3 метою вивчення можливостей допомогти людині та сім'ї в цілому зробити правильний життєвий вибір. На наш погляд, доцільним $є$ включення результатів тестування в роботу на заняттях у Школі прийомних батьків, оскільки, з одного боку, це сприятиме встановлення довірливих відносин, а 3 іншого - отримані дані психологічної оцінки можуть допомогти індивідуалізувати та оптимізувати процес підготовки замісних батьків. Проведення психологічного тестування має передувати навчанню замісних батьків, оскільки результати тестування $є$ допоміжним ресурсом для психолога, який далі проводить навчання кандидатів. Вивчення мотивації замісного батьківства доцільно проводити за допомогою інтерв'ю, оскільки можливість живого спілкування сприяє об'єктивності. Метою інтерв'ю є визначення кандидатів в замісні батьки, виокремлення індивідуальних характеристик конкретного кандидата, які мають пройти деталізацію на 
наступних етапах. Уточнення характеру мотивації відбувається за допомогою методики, що базується на попарному порівнянні мотивів. Вона дозволяє, з одного боку, виявити мотиви, найбільш і найменш значущі для кожного з подружжя і співставити їх між собою.

II eman психологічного обстеження - виявлення яскраво виражених протипоказань для виконання функцій замісних батьків. Реалізація цієї мети здійснюється через послідовне тестування.

III етапом є оцінка ресурсності кандидатів в замісні батьки. Мета цього етапу - виявлення ресурсних сторін замісних батьків, які $\epsilon$ передумовою успішного функціонування сім'ї перешкоджають поверненню дитини до інтернату. Для зниження ризику відмови від дитини замісна сім'я повинна володіти такими ресурсами, як: життєстійкість, ефективна сімейна комунікація, розвинені навички вирішення внутрішньо сімейних проблем, вміння доцільно розподіляти ресурси, об'єктивна оцінка матеріальних можливостей сім'ї [4, с. 90].

Отже, ефективність створення замісної сім'ї безпосередньо залежить від поєднання сімейних та індивідуальних ресурсів. Висока ресурсність замісного батьківства знижує прояви психопатологічної симптоматики батьків та дитини і полегшує взаємодію членів сім'ї один з одним, 3 прийомною дитиною, сприяючи їх взаємній адаптації.

\section{Література:}

1. Махнач, А.В. Роль ресурсности семьи при отборе кандидатов в замещающие родители / Психологический журнал. 2015. Т. 36, o 1. C. $108-122$.

2. Махнач, А.В. Психологическая диагностика кандидатов в замещающие родители. М. : Институт психологии РАН, 2013. 167c.

3. Постылякова, Ю.В. Индивидуальные и семейные ресурсы у кандидатов в замещающие родители/ Проблема сиротства в современной России: психологический аспект. М. : Институт психологии РАН, 2015. C. 459-477.

4. Постылякова Ю.В. Семейные ресурсы и индивидуальная жизнеспособность кандидатов в замещающие родители . Жизнеспособность человека: индивидуальные, профессиональные и социальные аспекты М. : Институт психо- логии РАН, 2016. С. 288-298.

5. H. Grotevant. Adoptive family system dynamics: Variations by level of openness in the adoption . Family Process. 1994. No 33(2). P. 125-146.

6. Boss P. Family stress. P. BoHandbook of Marriage and the Familyю. New York : Plenum, 1987. P. 695-723.

7. Brinich P. Psychoanalytic perspectives on adoption and ambivalence / P. Brinich // Psychoanalytic Psychology. 1995. No 12. P. 181-199. 
8. Cadoret R.. Early Life Psychosocial Events and Adult Affective Symptoms. New York : Cambridge University Press, 1990.

9. Palacios J. Social competence in internationally adopt ed and institutionalized children . Early Childhood Research Quarterly. 2013. No 28 (2). P. 357-365.

10. Tooley U.A. Nutritional status of foster children in the US: Implications for cognitive and behavioral development . Children and Youth Services Review. 2016. No 70. P. 369-374. 